ADALAH : Buletin Hukum \&

Keadilan

Buletin Hukum \& Keadilan

@adalahuinjkt

\title{
Penegakan Hukum Berkeadilan Sebagai Perwujudan Demokrasi Indonesia
}

Pemegang kedaulatan tertinggi di Indonesia adalah rakyat, yang menunjukkan Indonesia adalah negara demokrasi. Hal ini berdasarkan Undang-Undang Dasar 1945 Pasal 1 ayat (2) yang berbunyi: "Kedaulatan adalah di tangan rakyat dan dilaksanakan menurut Undang-Undang Dasar". (Sodikin, 2014: 106). Bagi suatu negara demokrasi, pastilah menjadikan pula 'hukum' sebagai salah satu asasnya yang lain. Ada dua bukti otentik dan konstitusional bahwa Indonesia berasas negara hukum. Pertama, disebutkannya secara eksplisit di dalam Undang-Undang Dasar 1945 Pasal 1 ayat (3) bahwa Indonesia ialah negara yang berdasar atas hukum (rechtsstaat) tidak berdasarkan atas kekuasaan (machstaat)". Kedua, negara Indonesia sudah memenuhi persyaratan untuk disebut sebagai negara hukum.

Menurut A. Muhammad Asrun dalam tulisannya menyatakan bahwa, dalam dua konsep tersebut yakni negara hukum dan demokrasi diintrodusir adanya perlindungan hak warga negara, karena perlindungan hak asasi adalah salah satu elemen dalam cita negara hukum dan perlindungan hak warga negara merupakan manifestasi kedaulatan rakyat yang merupakan unsur penting dalam konsep demokrasi. (Asrun, 2016: 138). Konsep negara hukum

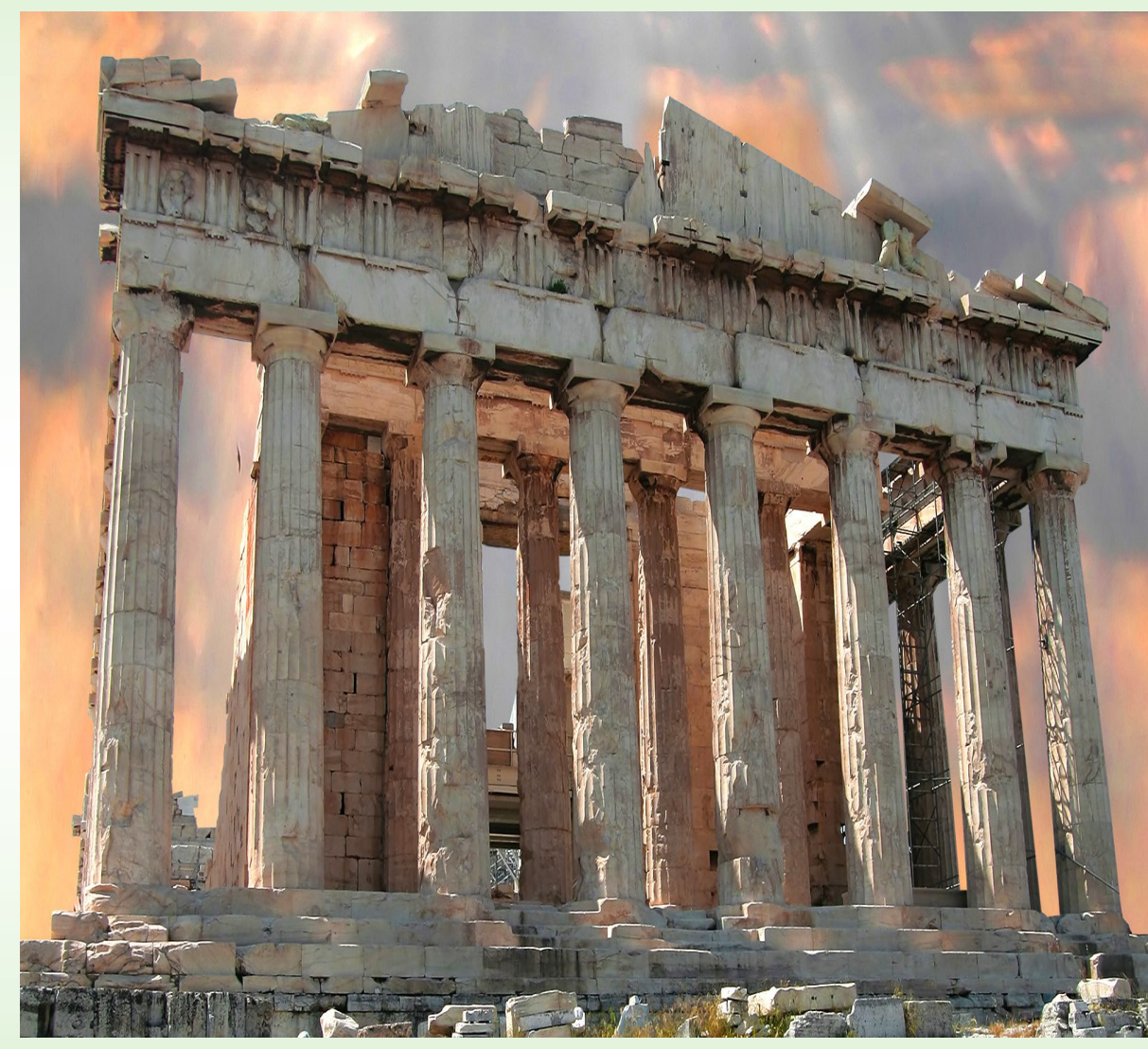

dimaksudkan sebagai usaha untuk membatasi kekuasaan penguasa negara agar tidak menyalahgunakan kekuasaan untuk menindas rakyatnya. Dengan diberlakukannya hukum yang adil diharapkan semua orang dalam negara tersebut tunduk pada hukum, sehingga setiap orang mempunyai kedudukan sama di mata hukum yang tidak memihak hanya pada sebagian kelompok dan membatasi kewenangan pemerintah berdasarkan prinsip distribusi kekuasaan, agar pemerintah tidak bertindak sewenang-wenang dan melindungi hak-hak rakyat sesuai kemampuan dan peranannya secara demokratis (Yunus: 2017: 55).

Namun masalahnya sekarang ialah dalam praktek di lapangan masih banyak terjadi pelanggaranpelanggaran terhadap hukum tersebut. Hukum yang semula diharapkan menjadi tiang penyangga dan alat untuk membangun kehidupan yang berkeadilan dan berkepastian dalam masyarakat yang tertib, ternyata 
dilanda krisis yang tak kalah hebatnya. Korupsi, konflik daerah, dan tindakan kekerasan kini marak terjadi di Indonesia. Setelah memasuki masa reformasi yang hendak menjadikan pembangunan hukum sebagai salah satu agendanya, Indonesia terjebak ke dalam ironi. Pertama, Indonesia diketahui secara internasional sebagai salah satu negara paling korup di dunia, namun sangat jarang koruptor yang dapat dijerat dengan hukum. Kedua, secara konstitusional Indonesia telah menetapkan dirinya sebagai negara hukum, tetapi dalam kenyataannya hukum tidak dapat ditegakkan dengan baik. Itu semua memberi kesimpulan bahwa peran hukum dalam reformasi masih sangat lemah dan tidak menunjukkan kinerja yang efektif.

Tidak sedikit pelanggaran HAM yang terjadi di Indonesia. Moh Mahfud MD menguraikan diantara pelanggaran hukum yang banyak terjadi yaitu adakalanya orang yang menurut rasa keadilan harus ditahan namun kenyataannya tidak ditahan, sebaliknya orang yang menurut kewajaran tidak perlu ditahan namun kenyataannya malah ditahan. Tidak jarang juga masyarakat tertahan lamanya nasib suatu perkara, apakah akan dilimpahkan ke pengadilan atau tidak, bahkan sering ditengarai adanya permainan untuk meneruskan atau menghentikan proses suatu perkara pidana dengan pembayaran tertentu. Bagi mereka yang memiliki uang, suatu kasus bisa dibeli agar tidak diteruskan ke pengadilan dengan kesimpulan 'tidak cukup bukti' dan karenanya dikeluarkan Surat Perintah Penghentian Penyidikan. (Mahfud MD, 2011: 178). Akibatnya, hukum kemudian menjadi alat permainan untuk mencari kemenangan di dalam sengketa atau berperkara di pengadilan dan bukan untuk menegakkan keadilan, kebenaran, dan ketertiban di dalam masyarakat. Bahkan orang yang mengadukan atau menyampaikan laporan terjadinya tindak pidana, tidak jarang malah dijadikan tersangka dan diperas dengan sejumlah uang agar tidak diproses lebih lanjut. Semua ini jelas merupakan pelanggaran atas UU yang mengatur tentang proses hukum dalam memperlakukan kasus-kasus pidana seperti yang diatur dalam UU Nomor 14 Tahun 1970 maupun di dalam Kitab Undang-Undang Hukum Acara Pidana.

Akan tetapi mengapa penegakan hukum dirasakan tidak menunjukkan hasil? Memang tepat untuk memperbaiki kinerja hukum harus didahului dengan perombakan struktur politik agar ia menjadi demokratis, hal yang menjadi masalah sebenarnya adalah pelaksanaan dari perubahan tidak berjalan dengan tuntas. Jadi, pelaksanaan hukum di Indonesia sangat tergantung pada kesadaran dan tanggung jawab masyarakat akan pentingnya hukum juga terhadap para penegak hukum yang melaksanakan tugasnya dengan baik sesuai peran yang dimiliki.[]

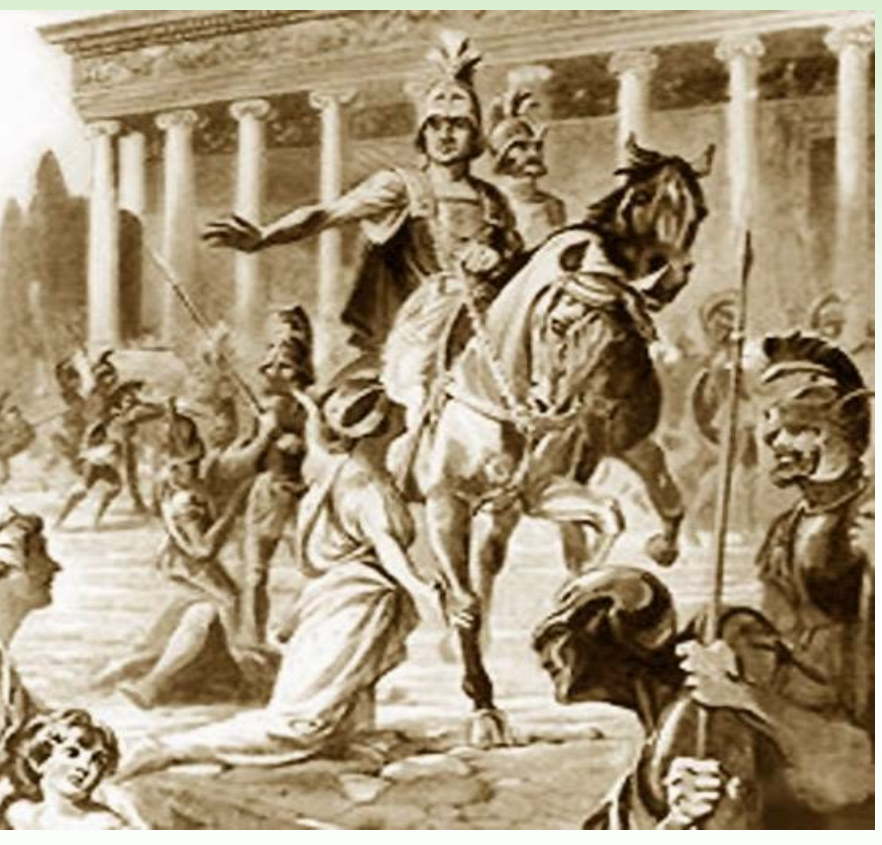

Pustaka Acuan:

* Penulis adalah pengamat Hukum dan Keadilan UIN Syarif Hidayatullah Jakarta dan merupakan mahasiswi FSH UIN Jakarta.

Mahfud MD, Moh, Dasar dan Struktur Ketatanegaraan Indonesia, Jakarta: Rineka Cipta. 2001.

A. Muhammad Asrun, "Hak Asasi Manusia Dalam Kerangka Cita Negara Hukum," Jurnal Cita Hukum, Volume 4 No. 1 (2016).

Sodikin, "Kedaulatan Rakyat dan Pemilihan Kepala Daerah Dalam Konteks Undang-Undang Dasar Negara Republik Indonesia Tahun 1945," Jurnal Cita Hukum, Volume 2 No. 1 (2014).

Yunus, Nur Rohim, Teori Dasar Penelitian Hukum Tata Negara, Jakarta: Poskolegnas, 2017.

'Adalah; Buletin Hukum dan Keadilan merupakan berkala ilmiah yang diterbitkan oleh Pusat Studi Konstitusi dan Legislasi Nasional (POSKO-LEGNAS), Fakultas Syariah dan Hukum UIN Syarif Hidayatullah Jakarta.

Penasehat: Prof. Dr. H. Abdul Ghani Abdullah, SH., Prof. Dr. H. A Salman Maggalatung, SH., MH. Pemimpin Redaktur: Indra Rahmatullah, Tim Redaktur: Nurrohim Yunus, Fathuddin, Mara Sutan Rambe, Muhammad Ishar Helmi, Erwin Hikmatiar. Penyunting: Latipah, Siti Nurhalimah. Setting \& Layout: Siti Romlah 